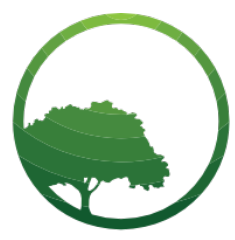

Business \& Social Science IJRBS

\section{Research in Business and Social Science}

IJRBS Vol 8 No 4, ISSN: 2147-4478

Contents available at www.ssbfnet.com/ojs

\title{
Effect of Vendor Characteristics and Relationship Quality on Consumer Re-Purchase Intention in the B2C E-Commerce in Yemen
}

\section{Mohammed Nasser Hadi}

Corresponding Author: School of Management, University of Science and Technology of China, Hefei, China.

\section{Ali N. Hadi}

School of Management, Hefei University of Technology, Hefei, China.

\section{Mohammed A. Abdulrab}

School of Management, Hefei University of Technology, Hefei, China.

\begin{abstract}
This study attempted to establish the relationship between vendor characteristics and relationship quality on consumer B2B E-commerce in Yemen. E-commerce is gaining a lot of attention especially in the Arabian world, as such we formulated and tested a model to explain $B 2 C$ user repurchase intention from the perspective of relationship quality. The model was empirically tested through a survey conducted in Yemen. Results showed that online relationship quality and perceived website usability positively impacted customer repurchase intention. Moreover, online relationship quality was positively influenced by perceived vendor expertise in order fulfillment, perceived vendor reputation, and perceived website usability. Trust in vendor behavior predominantly influenced online relationship quality and subsequent purchase intention. Implications of these findings are discussed.
\end{abstract}

Key words: Re-Purchase Intention, Vendor Characteristics, Relationship Quality, B2B E-commerce.

JEL classification: 030

Submitted: 07.06.2019 - Accepted: 27.06.2019

\section{Introduction}

In recent times, the deepening, development, and promotion of internet, and information technology, has resulted to significant increase in the utilization of E-Commerce platforms. This is becoming a common trend in the Arabian Peninsula as a result of effects globalisation emanating from the major blocks of the Arab league led by United Arab Emirates and Saudi Arabia. One explanation to this is the increased use of internet and decline in social and cultural restrictions. In recent years, Yemen's e-commerce market is developing very rapidly. Despite the Yemen's civil war of 2015, which greatly disrupted its E-Commerce, the total ecommerce sales increased to RMB5.88 trillion (US $\$ 94.4$ billion) in 2017, a year-on-year increase of $12.9 .2 \%$ 
from 2016, which accounts for $4.32 \%$ of total retail sales in Yemen (Walters et al. 2017). The term businessto-consumer (B2C) refers to the process of selling products and services directly to consumers who are the end-users of its products or services(Banjo, 2013).

Most companies that sell directly to consumers can be referred to as $\mathrm{B} 2 \mathrm{C}$ companies. The major advantage of this model of business is that it enables companies to directly leverage on the rich consumer bases in certain market segments(Laudon \& Traver, 2016), without subjecting their goods to the chain of distribution. Besides, B2B entities stand to benefit on consumer trust and loyalty that builds over time as a result of continuous B2B engagements(Houjeir \& Brennan, 2014). This relationships which is built over time has been intimated to have substantial contribution to E-Commerce platform consumer behavior(Zeffane \& Bani Melhem, 2017). One of the aspects of E-Commerce which has been shown to influence consumer purchasing behavior is the characteristics and quality of the E-Commerce platform. By characteristics, it implies the perceived aspects of the platform like, perceived website usability, perceived expertise in order fulfillment, perceived reputation, and trust in the vendor(Aladwani, 2003). T

his study therefore sought to establish how these characteristics influenced re-purchase intention in Yemen B2B E-commerce.

\section{Literature Review}

Scholarly studies on factors influencing consumer purchase intention or re-purchase intention from B2B ECommerce platforms have focused on consumer perception of the vendor characteristics and quality of the relationship between the vendor, online platform, and quality of the product sold through the platform(Ganguly, Dash, \& Cyr, 2009; Zeffane \& Bani Melhem, 2017). Findings from these studies have either been inconclusive, biased or devoid of suitable methodology. One major dimension of E-commerce in the Arabian Peninsula, is the censorship of internet which moderates consumer behaviour towards ECommerce platforms. Another aspect is the undeveloped E-Commerce platforms in Yemen especially because of long periods of civil strife, coupled with the cultural impediments associated with the use of internet in the Arab-World(Aladwani, 2003). Online vendor characteristics has been found to greatly influence how online customers and virtual communities perceive, and interact with the vender's E-Commerce, with regards consumer buying behaviours. Becerra and Korgaonkar (2011), in their study on antecedents of ECommerce in the united Arab Emirates found out that trust in the vendor was their most influential determinant of re-purchase intention. Trust in the vendor extends beyond the beautiful images of the products in the E-commerce platform(Chen \& Dhillon, 2003), but delivery of the product to the consumer in the specification and quality that was displayed in the platform. Another dimension of the trust, is the ability of the vendor to execute the sale deal as stipulated in the terms and conditions displayed on the platform. This will include: the ability of the vendor to reimburse the money back to the buyer should the product delivered fail to meet the quality and usefulness as earlier stipulated on the platform(Ganguly et al., 2009). Another dimension of online vendor characteristics is consumer-perceived reputation of the vendor(Yixiang Zhang et al., 2011). Brand reputation is closely associated with the quality and usefulness of the brand(Abyad, 2011). Evidence alludes that vendors with high reputation have high online presence and remarkable consumer to consumer references(Fuller, Serva, \& Benamati, 2007). Thus, corporate reputation and brand reputation have great potential to enhance trust in companies selling on the Internet is supported by the observation that users of price intermediaries do not necessarily choose the cheapest offer, but regularly buy from branded and widely known retailers even when these do not offer the lowest price. Reputation serves as a 'hostage' in the hands of the customer(Abyad, 2011). This means that the reputation of an actor, for example a firm, can be destroyed by the customer who can spread the word of the actor's bad corporate practices in case he behaves in an opportunistic manner. Nevertheless, customer satisfaction negatively impacts on the firm's reputation. In such situations where the B2B buyers are disgruntled, the firms suffers backlash as a result lack of repeat purchase from the previous consumers(Oliveira, Alhinho, Rita, \& Dhillon, 2017).

Other studies on vendor characteristics intimate that usability of the E-commerce platform and perceived vendor expertise in order execution as being influential to consumer decisions of making first time or repeat purchase(Kong \& Hung, 2006). E-commerce platform's usability implies to the level of difficulty encountered by consumers in utilizing the E-Commerce platform to make an online purchase(Huang \& Benyoucef, 2013). 
In E-commerce platforms, the website represents the vendor. How simple it is in placing an order and make payments, influences the relationship quality between the buyer and the vendor. Some websites have unnecessarily long and bureaucratic process before one succeeds in placing and order and (or) making payments. This normally discourages first-time users. The previous experience of the consumer with the vendor will greatly influence his or her re-purchase intention. In the online context, fulfilling an order is completed by the online vendor either through the website (if the product is digital), or by offline means. Vendor expertise in fulfilling the order is critical in both instances. We therefore included this expertise as part of our model. Therefore, relationship quality between the vendor (B2B E-commerce platform), is greatly influenced by the vendor characteristics which include: usability of the online platform, level of expertise of vendor in receiving orders and executing them, the behavior of the vendor which touches on his level of trust, his reputation as perceived by the other E-commerce platform and online users and virtual communities(Hajli, Sims, Zadeh, \& Richard, 2017).

\section{Theory and Hypothesis}

This paper was guided by two theories: the theory of planned behaviour and the theory of reasoned action (TRA).

\section{The Theory of Planned Behaviour}

The theory of planned behaviour (TPB)(Ajzen, 1991), assumes that behavioral intentions capture the motivational influences on behavior. Intention is thus seen as the most proximal predictor of behavior(Ajzen, 2011; Huang \& Benyoucef, 2013). Behavioral intention, in turn, is seen as a function of attitudes, subjective norms and perceived behavioral control. The theory alludes that consumer behavior attitudes are based on cognitive beliefs. The beliefs emanate from the normal experiences between buyers and vendors(Ajzen, 2011). The theory assumes the normative and moral capacity of the consumer in exercising behavior towards a prevailing purchase intention choice. Previous studies have shown independent predictive effects of perceived moral obligation or personal norm on behavioral intentions in actions with moral implications, such as cheating, stealing and lying. Questionnaire measuring consumer behavior in line with the TPB measures of attitude, subjective norm, perceived behavioral control (PBC), behavioral intention and beliefs with the addition of measures of moral attitude, and affective attitudes(Ajzen, 1991; Huang \& Benyoucef, 2013). However, this predictive effects have been attributed to the underlying aspects inherent within the consumer like pervious experiences with the product, vendor or the vendor website, such experiences are perceived and classified based on the judgement made by the consumer. As such this theory is thus pertinent to this current study.

\section{Theory of Reasoned Action}

The theory of reasoned action(Belleau, Summers, Xu, \& Pinel, 2007; Fishbein, Jaccard, Davidson, Ajzen, \& Loken, 1980), postulates that individuals are rational and make systematic use of information available to them. The theory of planned behavior(Ajzen, 1991), extended the theory of reasoned action by including perceived behavioral control as a determinant of both behavioral intention and behavior. Inclusion of perceived behavioral control added significantly to the prediction of intention and behavior, especially for circumstances in which there were constraints on action. The theory of reasoned action can adequately predict behaviors that are relatively straightforward, that is, under volitional control (Armitage \& Conner, 2001). We believe that an intention to purchase an item is volitional and very few constraints exist. Therefore, we feel that using the theory of reasoned action will result in a valid prediction of purchase intention. This is informed by the premise that relationships between attitude and behavior can be informed by the variables of beliefs, attitudes, behavioral intentions, and behavior(Belleau et al., 2007).

\section{Theoretical Framework and Hypothesis.}

Based on the above two theories, a number of studies have tried to explain consumer behavior in a B2B ECommerce platform to try and explain consumer purchase and re-purchase intention. These theories will help in strengthening the results of the hypothetical findings on how consumers behave towards online B2B platforms in making purchases. The model below shows the relationship between vendor characteristics, relationship quality, and re-purchase intention of B2B consumers from an E-Commerce platform in Yemen. 


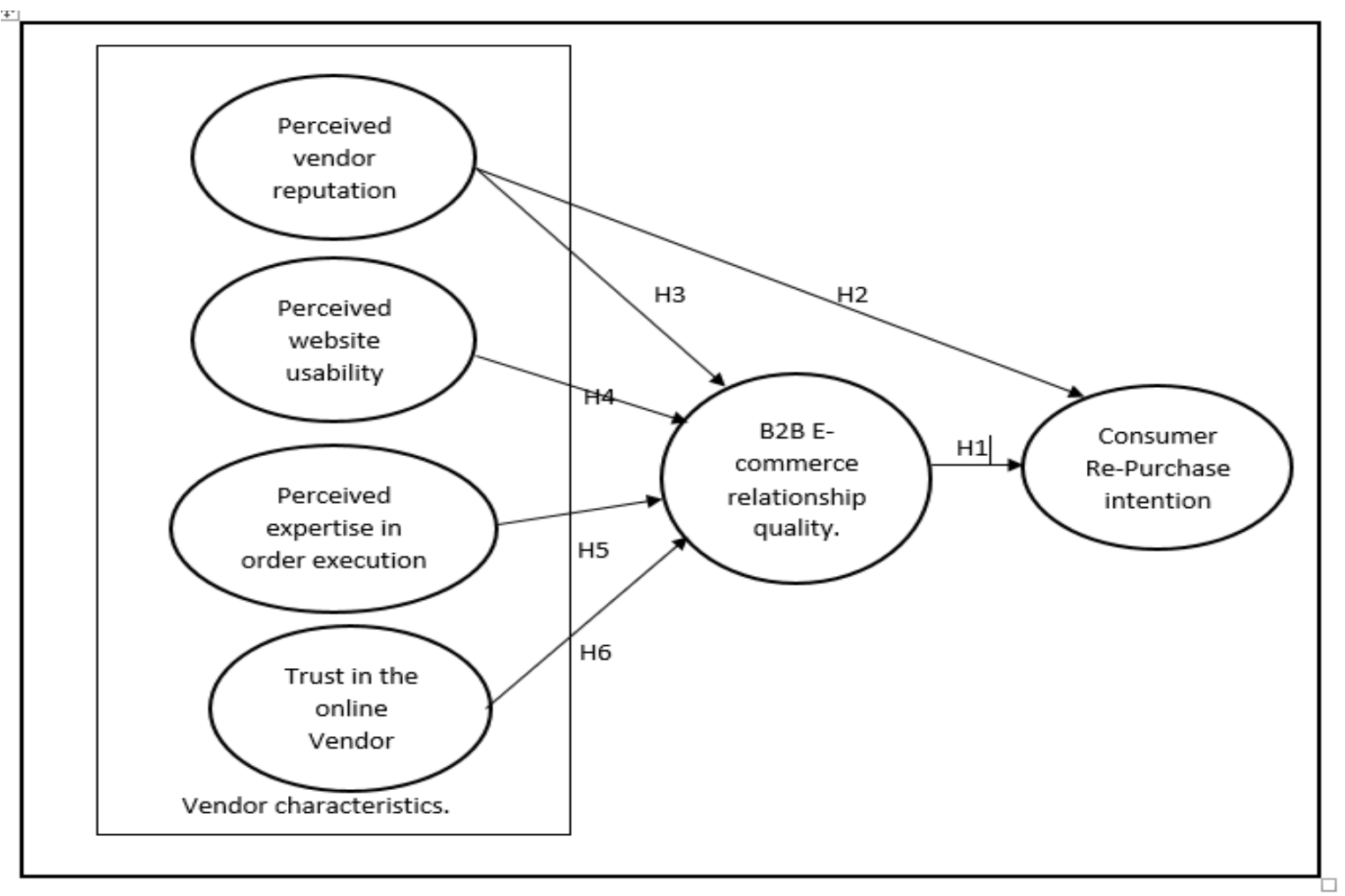

Figure1 : Conceptual Model.

\section{Online Relationship Quality and Consumer Purchase Re-Intention}

A buyer-seller relationship is considered high quality only when previous interaction with the vendor has been positive and future interactions with the seller are expected. A good relationship is developed only when buyers feel satisfied and have trust in their relationship with the vendor. We thus hypothesized:

Hypothesis 1. Online relationship quality is positively related to customer online repurchase intention.

\section{Online Vendor Characteristics}

\section{Usability of Vendor's Website, Relationship Quality, and Purchase Intention.}

Consumers use the vendor's website to find the product features, place orders and make online payments. The Vendors website should provide the consumer with product information in the simplest way possible with minimal technological input(Aladwani, 2003). In addition, a well-designed website with high usability (e.g., ease of navigation) can improve a consumer's online buying experiences and their perception of the vendor(Huang \& Benyoucef, 2013).(Yixiang Zhang et al., 2011), while applying the theory of reasoned action found out that the usability of the vendor's website was negatively associated to consumer perceived risk associated with online purchases. Yixiang Zhang et al. (2011), also found that buyers who perceived the website to be easier to register, log in, identify product and even make online payment greatly influenced their purchase intention, re-purchase intention, satisfaction, and ultimate trust and loyalty on the vendor. Lee, Moon, Kim, and Mun (2015), found that certain properties of a website (e.g., adequacy of product description and width of product selections) significantly influenced customer trust and that navigation functionality was a significant antecedent of customer satisfaction. In line with the findings of the studies above, this study postulates the relationship between the B2B vendors' website usability and consumer purchase intention in Yemen as follows: 
H4: Perceived Website Usability is positively related to online relationship Quality.

\section{Vendor Expertise and Timeliness in Order Fulfillment.}

The level of expertise of the vendor and timeliness in receiving and executing placed orders is a major factor in B2B E-Commerce. In this study, we measured vendor's level of expertise and timeliness in order execution as perceived by the customer. Customers perceive vendors to be of high expertise based on how long it takes between placing an online order and receiving the ordered product. Customer perceptions of order processing is important in influencing e-commerce success. It is also important for online customers to receive the product for which they have paid in a timely, efficient, and safe manner. When a customer's perception of online vendor expertise in order fulfillment is high, the customer believes that the vendor has the ability and relevant competencies associated with order fulfillment and is confident that he/she will obtain the product on time. This, in turn, increases his/her satisfaction and trust. Therefore, customers tend to develop long-term relationships when they perceive high vendor's expertise in order fulfillment. Based on the above relationships and findings, this study therefore hypothesis that:

H5: Perceived vendor expertise and timeliness in order fulfillment is positively related to online relationship quality.

\section{Online Vendor's Reputation.}

Company reputation has long been recognized as a critical factor in successfully marketing a service (Yixiang Zhang et al., 2011). The typical model of customer buying intention holds that company reputation interacts with both information about an offering and other elements of the marketing mix. A company's reputation reflects the history of its past actions(Kim \& Lennon, 2013), and affects the buyer's expectations with respect to the quality of its products(Abyad, 2011). A buyer's purchase intention as being determined by his/her expectation, which itself is strongly influenced by the company's reputation(Yixiang Zhang et al., 2011). Vendor reputation involves customer perceptions of the vendor's public image, innovativeness, quality of product and service, and commitment to customer satisfaction(Kong \& Hung, 2006; Yixiang Zhang et al., 2011). Customers can determine vendor reputation based on an evaluation of the vendor's past performance and behavior. Reputation is associated with brand equity and firm credibility; it is also viewed as a sign of trustworthiness. It is, however, difficult to build, but easy to lose. This requires the vendor to stay motivated to maintain a good reputation once it is established(Al-Ghaith, Sanzogni, \& Sandhu, 2010; Lee et al., 2015).Based on the findings above, this study hypothesis the relationship of vendor's reputation and relationship quality in Yemen B2B E-commerce as follows:

H3: Perceived vendor reputation is positively related to online relationship quality.

H2: Perceived vendor reputation is positively related to online repurchase intention.

\section{Trust in the vendor (E-commerce Website).}

In normal product distribution chain stores, trust in the supplier or distributor determines the purchasing intention of the consumers. However, in E-commerce, trust in the website is the proxy measure of trust in the vendor(Kim \& Lennon, 2013). When customers have distrust in vendor behavior, they believe that the vendor will not keep their promises. Distrust also implies violations of customer expectations(Yu Zhang, Bian, \& Zhu, 2013). For example, an online vendor may deliver low quality products. Trust in the vendor means minimal perception of fraud on customers. When trust is minimal, consumers will always have a feeling of fraud especially if the vendor delays to execute the order(Zeffane \& Bani Melhem, 2017). However, trust increases after the first purchase if the execution of the order was timely and the product bore the same quality as ordered by the customer(Yu Zhang et al., 2013). Accordingly, we posit a negative relationship between distrust in vendor behavior and online relationship quality:

H6: Trust in vendor behavior is positively related to online relationship quality.

\section{Control Variables.}

Several control variables were included in our model to rule out the possibility that empirical results were due to covariance with other variables. Some variables have been found to influence online consumers directly 
or indirectly, such as gender, levels of income and education, expertise in using the Internet, and familiarity with the vendor. We therefore included these factors as control variables. Yemen being an Islamic country with strong cultural and social norms, most of the control variables mentioned above could greatly influence the re-purchase intention.

\section{Research and Methodology}

This section included the methodology that was used by the paper. It mentions the research sampling design that were used as well as the sample size and analytical technique.

\section{Measurement of Variables}

Several control variables were included in our model to rule out the possibility that empirical results were due to covariance with other variables. Some variables have been found to influence online customers directly or indirectly, such as gender, levels of income and education, expertise in using the Internet, and familiarity with the vendor. We therefore included these factors as control variables. The scales used were all multi-item and responses were recorded via a seven-point Likert type format with endpoints of strongly disagree (1) and strongly agree (7). The sources of the measurement as well as the measurements for each construct are shown in appendix 1. A semi-structured questionnaire was put online and widely publicized in the Yemen social media. A sample of 670 respondents was deemed enough for the data analysis. Our sample covered a broad collection of online vendors, with the four most frequently cited vendors being (1) SOUQ $(21 \% ; n=$ 77); (2) Amazon (16\%; $n=58) ;(3)$ BrandsBay (6\%; $n=23)$; and (4) Namshi (6\%; $n=23)$. The response rate for our online questionnaires was $88 \%$. We however checked our no-response rate by comparing the first and last $10 \%$ of the responses on all the main constructs using a Mann-Whitney U-test. None of the tests were statistically significant, indicating that non-response bias was not a problem.

\section{Data Analysis}

First, a confirmatory factor analysis was done to assess the measurement model. Second, the structural model was examined. We used Smart PLS to conduct the analysis. Bootstrapping with 500re-samples and 360 cases per sample was used to assess the path significance.

\section{Measurement Model and Model Fitness}

The reliability was checked using Cronbach alpha, with only measures with a value of 0.7 and above retained. Construct loadings were examined, with values greater than 0.7 being retained and items with loadings lower than 0.7 being dropped. The model was then re-examined. All of the remaining items loaded sufficiently on the relevant construct $(P<0.01)$. The number of items, composite reliability, and average variance extracted in the final measurement are shown in table 2. I. Finally, checked the composite reliability and the lowest value for all the constructs was 0.85 , which was by way higher than the recommended level of 0.7 , implying good reliability. Convergent validity was assessed by examining average variance extracted (AVE) from the measures; it ranged from 0.61 to 0.78 , well above the recommended value of 0.5 , thus showing convergent validity. The convergent reliability results are shown in table 2 .Discriminant validity was determined using a correlational matrix among the constructs and control variables. Construct validity was ascertained using AVE values. The square root of the AVE for each construct was larger than the correlation of any specific construct with any of the other constructs, showing that we had discriminant validity. The constructs validity results are shown in appendix $B$.

Table 1: Correlational Matric between Constructs

\begin{tabular}{llllllllll}
\hline & Mean & Std Dev & PEO & CSAT & VTRU & ORI & PR & PWU & CUEX \\
\hline PEO & 5.57 & 1.26 & $\mathbf{0 . 8 7}$ & & & & & & \\
\hline
\end{tabular}




\begin{tabular}{llllllllll}
\hline CSAT & 5.64 & 1.28 & 0.42 & $\mathbf{0 . 8 4}$ & & & & & \\
VTRU & 5.85 & 1.43 & 0.65 & 0.45 & $\mathbf{0 . 8 5}$ & & & & \\
ORI & 4.97 & 1.27 & 0.44 & 0.40 & 0.47 & $\mathbf{0 . 8 9}$ & & & \\
PR & 5.23 & 1.56 & 0.25 & 0.40 & 0.46 & 0.67 & $\mathbf{0 . 7 9}$ & & \\
PWU & 5.79 & 1.51 & 0.52 & 0.32 & 0.34 & 0.54 & 0.35 & $\mathbf{0 . 8 2}$ & \\
CUEX & 5.39 & 1.49 & 0.20 & 0.24 & 0.36 & 0.28 & 0.23 & 0.21 & $\mathbf{0 . 8 7}$ \\
\hline
\end{tabular}

Note: SD, standard deviation; PEO, perceived expertise in order fulfillment; CSAT, Customer satisfaction; VTRU, Vendor trust; PR, Perceived reputation; PWU, perceived website usability; CUEX, customer expertise in using Internet; Values in the diagonal row are square roots of the average variance extracted. The other cells contain the correlations between constructs.

\section{Discussions and Finding}

After checking the validity of the constructs, we run the model using SEM in Smart PLS. The table below shows the structural model including the path coefficients along with their $\mathrm{R}^{2}$. Our model explained $34 \%$ of the variance of online repurchase intention and $62 \%$ of the variance of online relationship quality.

Table 2: Multiple regression results

\begin{tabular}{lll}
\hline Measure of Vendor Characteristics & \multicolumn{2}{c}{ Beta Coefficients } \\
\cline { 2 - 3 } Perceived vendor reputation & Online relationship quality & Online Re-purchase intention \\
\cline { 2 - 3 } Perceived website usability & $\left(\mathrm{H}_{3}\right)$ & $0.24^{* *}\left(\mathrm{H}_{2}\right)$ \\
Perceived expertise in order execution & $0.20^{* *}\left(\mathrm{H}_{4}\right)$ & \\
Trusts in online vendor & $0.36^{* * *}\left(\mathrm{H}_{5}\right)$ & \\
Perceived relationship Quality & $0.24^{* * *}\left(\mathrm{H}_{6}\right)$ & $0.34^{* * *}\left(\mathrm{H}_{1}\right)$ \\
$F$ & & $6.486^{\star * *}$ \\
$R^{2}$ & $9.364^{* * *}$ & 0.34 \\
\hline
\end{tabular}

Hypothesis 1 posited that online relationship quality positively influences repurchase intention. The path coefficient of $0.34(p<0.001)$, supporting this hypothesis. The influence of perceived vendor reputation on online repurchase intention was positive and significant (coefficient of $0.24, p<0.001$ ), providing support for Hypothesis 2. Hypothesis 4 posited that perceived website usability positively influenced online relationship quality. This was supported by the significant path coefficient of $0.20(p<0.01)$. The positive impact of perceived vendor expertise in order fulfillment on relationship quality was also confirmed (coefficient of 0.36 , $p<0.001$ ), supporting Hypothesis 5. Our data also supported Hypothesis 4 (coefficient of 0.26, $p<0.001$ ). Our result also showed a positive effect of trust in vendor behavior on online relationship quality (coefficient of $0.24, p<0.001$ ), which confirmed, Hypothesis 6 . We did not find any significant relationship between the control variables and online repurchase intentions. The relationship between the control variables and repurchase intention was insignificant. 


\section{Discussions and implications, and Limitations}

This section consists of major discussions pertaining the findings above, their implication to the theory and practice as well as their limitations.

\section{Research Implications.}

This study attempted to establish the conjoined relationship (if any) between consumer trust and satisfaction, and determined its influence on consumer re-purchase intention. This attempt is a deviation from the norm where the two constructs were studied separately. By use of second order relationship quality, this study obtained a very parsimonious model and used it in ascertaining the relationship between vendor characteristics and re-purchase intention. In recent times, studies in marketing research has shifted from transaction marketing to relationship marketing. In the B2B E-commerce industry, relationship marketing is very pertinent. Our study revealed that online relationship quality is influenced by all the antecedents: vendor characteristics (website usability, expertise in order fulfillment and reputation) and vendor behavior (trust in vendor behavior). On the same note, consumer familiarity as well as vendor reputation were positively associated with re-purchase intention. Studies on antecedents allude that for first time buyer(Lee et al., 2015; Zeffane \& Bani Melhem, 2017), their experience in making an online purchase determines a lot the subsequent purchases. One of the experiences is how user-friendly the vendor's website is with respect to identifying what one needs to buy, negotiating for prices, placing an order and making payments. If this experience is positive and good, then the reputation of the vendor increases and ultimately implies a possibility of repeat purchase.

Vendor Website usability depends on product information presentation and ease of conducting transactions. Order fulfillment should focus on post-purchase service. The empirical data showed that perceived vendor expertise in order fulfillment had a greater impact on online relationship quality than perceived website usability. This is important. There have been very few studies on B2C e-commerce retention that have focused on the post-purchase stage of order fulfillment especially in the Arab world which is characterized with internet censorship. We showed the importance of considering the post-purchase stage of order fulfillment. Furthermore, the greater impact of order fulfillment implies that vendor post-purchase expertise is more important for online relationship quality than expertise in online activities. Product delivery is important.

We also studied another vendor characteristic: perceived vendor reputation. This was not included as an antecedent of relationship quality but is considered very important. Prior research on $\mathrm{B} 2 \mathrm{C}$ ecommerce found that vendor reputation was important as it can influence consumer behaviors. Our study revealed that perceived reputation was important: it positively impacts online relationship quality, extending the original offline relationship quality model. This study established that vendor reputation is determined by how effective and timely he executes the orders, consumer experiences with the products and post-purchase relationship between the buyer and the seller, what is famously known as post-consumer purchase follow-up. This follow up is essential to establish if the customer was impressed with the quality of the product he received and any consumption reservation he could be having.

\section{Managerial Implications}

This study poses a number of managerial implications in line with consumer behavior in B2B platforms. First, this study was carried in Yemen which is part of Arab World. Despite the cultural and social restrictions in the Arab World, especially in Yemen, E-commerce is thriving. However, unlike emerging economies like India, UAE, and China, E-commerce is not well developed in Yemen, leading to a lot of consumer attention to mainstream E-commerce platform like the China Alibaba, Amazon etc. Website usability was found to positively influence both relationship quality and repurchase intention, showing that online vendors should be more considerate of the role of the website and work to improve user experience by providing rich product information, improving website navigation functions, and making online purchasing easier. Expertise in order fulfillment was found to be an important antecedent of relationship quality, showing that online vendors should demonstrate their expertise in order to increase customer loyalty and retention. 
For example, they could provide professional testimonies and publish on-time delivery statistics. Mangers of e-commerce website can also improve online relationship quality by establishing and sustaining a good reputation thus promoting customer loyalty and retention. The implication of this to the management of the E-commerce platforms of those MNC's operating from UAE, and those whose base of operation is Yemen is as follows: First, their E-commerce platform must be very easy to navigate, be done in languages which can be understood by the majority, besides English, and must have high usability. Secondly, vendors must increase mechanisms that guarantee high reputation of their platform as well as increase consumer trust in them. This will increase new online purchase and re-purchase intention.

\section{Limitations of the Study}

This research had few limitations. First, not all the categories of the consumers were included in the sample due to difficulties in sampling the heterogeneous Yemen society. Caution must therefore be exercised when attempting to generalize our results to other locations. Also, since the respondents self-selected the online vendor from whom they had purchased material in order to answer the questionnaire, social desirability bias may be present - although it may be observed that the data had enough variability to make model testing possible. The study was limited with regards to the duration it took to be completed and the number of constructs involved in the study. Other important constructs pertinent to this study could have been left out, however the findings were not jeopardized.

\section{Conclusions}

This study is designed to establish the relationship between vendor characteristics and B2B E-commerce relationship quality on consumer re-purchase intention. The study developed and tested a model explaining B2C ecommerce customer repurchase intention from a relationship quality perspective. By including vendor characteristics (perceived website usability, perceived expertise in order fulfillment and perceived reputation) and vendor behavior (distrust in vendor behavior), our model explained the importance of online relationship quality to online re-purchase intention. To a certain degree, our study demonstrated the value of using relationship marketing theory to account for online customer repurchasing behavior. Its results should provide useful implications for ecommerce practitioners. However, the other two theories of consumer behavior i.e. theory of planned behavior and theory of reasoned action featured greatly in this study and influenced the theoretical framework. This study concluded that B2B E-commerce platform must ensure their websites are user-friendly, and that orders placed should be executed as soon as possible. This will greatly influence the reputation of the website which is the reputation of the vender and whole organization.

\section{References}

Abyad, A. (2011). Consumer trust in e-commerce. Middle East journal of business, 55(2412), 1-4.

Ajzen, I. (1991). The theory of planned behavior. Organizational behavior and human decision processes, 50(2), 179-211. http://dx.doi.org/10.1016/j.obhdp.2010.11.001

Ajzen, I. (2011). The theory of planned behaviour: reactions and reflections: Taylor \& Francis. https://doi.org/10.1080/08870446.2011.613995

Al-Ghaith, W., Sanzogni, L., \& Sandhu, K. (2010). Factors influencing the adoption and usage of online services in Saudi Arabia. The Electronic Journal of Information Systems in Developing Countries, 4O(1), 1-32. https://doi.org/10.1002/j.1681-4835.2010.tb00283.x

Aladwani, A. M. (2003). Key Internet characteristics and e-commerce issues in Arab countries. Information Technology \& People, 16(1), 9-20. https://doi.org/10.1108/09593840310462998.

Banjo, O. (2013). B2B marketing communications in emerging markets: content marketing in digital channels: a case study of the United Arab Emirates.

Becerra, E. P., \& Korgaonkar, P. K. (2011). Effects of trust beliefs on consumers' online intentions. European Journal of marketing, 45(6), 936-962. https://doi.org/10.1108/03090561111119921

Peer-reviewed Academic Journal published by SSBFNET with respect to copyright holders. 
Belleau, B. D., Summers, T. A., Xu, Y., \& Pinel, R. (2007). Theory of reasoned action: Purchase intention of young consumers. Clothing and Textiles Research Journal, 25(3), 244-257. https://doi.org/10.1177\%2F0887302X07302768

Chakraborty, G., Lala, V., \& Warren, D. (2002). An empirical investigation of antecedents of B2B Websites' effectiveness. Journal of interactive marketing, 16(4), 51-72. https://doi.org/10.1002/dir.10044

Chen, S. C., \& Dhillon, G. S. (2003). Interpreting dimensions of consumer trust in e-commerce. Information technology and management, 4(2-3), 303-318. http://dx.doi.org/10.1023/A:1022962631249

Fishbein, M., Jaccard, J., Davidson, A. R., Ajzen, I., \& Loken, B. (1980). Predicting and understanding family planning behaviors Understanding attitudes and predicting social behavior: Prentice Hall.

Fuller, M. A., Serva, M. A., \& Benamati, J. S. (2007). Seeing is believing: The transitory influence of reputation information on e-commerce trust and decision making. Decision Sciences, 38(4), 675-699. https://doi.org/10.1111/j.1540-5915.2007.00174.x

Ganguly, B., Dash, S. B., \& Cyr, D. (2009). Website characteristics, Trust and purchase intention in online stores:-An Empirical study in the Indian context. Journal of Information Science \& Technology, 6(2).

Gefen, D. (2002). Customer loyalty in e-commerce. Journal of the association for information systems, 3(1), 2. $10.17705 / 1$ jais. 00022

Hajli, N., Sims, J., Zadeh, A. H., \& Richard, M.-O. (2017). A social commerce investigation of the role of trust in a social networking site on purchase intentions. Journal of Business Research, 71, 133-141. https://doi.org/10.1016/j.jbusres.2016.10.004

Houjeir, R., \& Brennan, R. (2014). Cultural influences on the antecedents of trust in B2B relationships: A study of Financial Services in the United Arab Emirates. https://doi.org/10.1108/IJBM-05-20160075

Huang, Z., \& Benyoucef, M. (2013). From e-commerce to social commerce: A close look at design features. Electronic Commerce Research and Applications, 12(4), 246-259. doi: https://doi.org/10.1016/j.elerap.2012.12.003

Kim, J., \& Lennon, S. J. (2013). Effects of reputation and website quality on online consumers' emotion, perceived risk and purchase intention: Based on the stimulus-organism-response model. Journal of Research in Interactive Marketing, 7(1), 33-56. https://doi.org/10.1108/IJBM-05-2016-0075

Kong, W.-C., \& Hung, Y.-T. C. (2006). Modeling initial and repeat online trust in B2C e-commerce. Paper presented at the Proceedings of the 39th Annual Hawaii International Conference on System Sciences (HICSS'06). http://dx.doi.org/10.1109/HICSS.2006.354

Laudon, K. C., \& Traver, C. G. (2016). E-commerce: business, technology, society.

Lee, D., Moon, J., Kim, Y. J., \& Mun, Y. Y. (2015). Antecedents and consequences of mobile phone usability: Linking simplicity and interactivity to satisfaction, trust, and brand loyalty. Information \& Management, 52(3), 295-304. https://doi.org/10.1016/j.im.2014.12.001

McCole, P., Ramsey, E., \& Williams, J. (2010). Trust considerations on attitudes towards online purchasing: The moderating effect of privacy and security concerns. Journal of Business Research, 63(9-10), 1018-1024. https://doi.org/10.1016/j.im.2014.12.001

Oliveira, T., Alhinho, M., Rita, P., \& Dhillon, G. (2017). Modelling and testing consumer trust dimensions in e-commerce. Computers in Human Behavior, 71, 153-164. https://doi.org/10.1016/j.chb.2017.01.050

Qureshi, I., Fang, Y., Ramsey, E., McCole, P., Ibbotson, P., \& Compeau, D. (2009). Understanding online customer repurchasing intention and the mediating role of trust-an empirical investigation in two developed countries. European Journal of Information Systems, 18(3), 205-222. http://doi.org/10.1057/ejis.2009.15 
Zboja, J. J., \& Voorhees, C. M. (2006). The impact of brand trust and satisfaction on retailer repurchase intentions. Journal of services marketing, 20(6), 381390. https://doi.org/10.1108/08876040610691275.

Zeffane, R., \& Bani Melhem, S. J. (2017). Trust, job satisfaction, perceived organizational performance and turnover intention: A public-private sector comparison in the United Arab Emirates. Employee Relations, 39(7), 1148-1167. https://doi.org/10.1108/ER-06-2017-0135

Zhang, Y., Bian, J., \& Zhu, W. (2013). Trust fraud: A crucial challenge for China's e-commerce market. Electronic Commerce Research and Applications, 12(5), 299-308.

Zhang, Y., Fang, Y., Wei, K.-K., Ramsey, E., McCole, P., \& Chen, H. (2011). Repurchase intention in B2C e-commerce-A relationship quality perspective. Information \& Management, 48(6), 192-200. 
Appendix A.

\begin{tabular}{|c|c|c|c|}
\hline & Construct & Measurements & Source \\
\hline \multirow[t]{4}{*}{1} & \multirow[t]{4}{*}{$\begin{array}{l}\text { Perceived expertise } \\
\text { in order Fulfilment }\end{array}$} & & \multirow[t]{4}{*}{$\begin{array}{l}\text { (Qureshi et al., } \\
\text { 2009) }\end{array}$} \\
\hline & & $\begin{array}{l}\text { believe that this vendor has knowledge and expertise in } \\
\text { distribution of the product }\end{array}$ & \\
\hline & & $\begin{array}{l}\text { I believe that this vendor has an efficient system for } \\
\text { processing orders received }\end{array}$ & \\
\hline & & $\begin{array}{l}\text { I believe that this vendor has efficiently integrated all } \\
\text { necessary departments/systems that are needed to } \\
\text { deliver products or services }\end{array}$ & \\
\hline \multirow[t]{4}{*}{2} & \multirow[t]{4}{*}{ Trust in the vendor } & The vendor does not fail to deliver exactly what I ordered & \multirow{3}{*}{$\begin{array}{l}\text { (Qureshi et al., } \\
\text { 2009) }\end{array}$} \\
\hline & & $\begin{array}{l}\text { I believe that the quality advertised is quality to be in the } \\
\text { product }\end{array}$ & \\
\hline & & Vendor is timely in his deliveries & \\
\hline & & I believe and price of product commensurate to quality & \\
\hline \multirow[t]{5}{*}{3} & \multirow{5}{*}{$\begin{array}{l}\text { Perceived website } \\
\text { usability }\end{array}$} & The site is extremely easier to use & \\
\hline & & The procedure of accessing site is not hard & \multirow[t]{4}{*}{ (Gefen, 2002) } \\
\hline & & The site is systematic and organized & \\
\hline & & Easy to identify the right product & \\
\hline & & Easy to make payment or cancel the order & \\
\hline \multirow[t]{4}{*}{4} & \multirow{4}{*}{$\begin{array}{l}\text { Customer expertise } \\
\text { in using internet to } \\
\text { conduct tractions }\end{array}$} & I know a lot about conducting purchases via the Internet & \multirow{4}{*}{$\begin{array}{l}\text { Modified from } \\
\text { (Chakraborty, } \\
\text { Lala, \& Warren, } \\
\text { 2002) }\end{array}$} \\
\hline & & am informed about conducting purchases via the Internet & \\
\hline & & $\begin{array}{l}\text { I am experienced in conducting purchases via the } \\
\text { Internet }\end{array}$ & \\
\hline & & I am an expert buyer of products/services via the Internet & \\
\hline \multirow[t]{4}{*}{5} & \multirow[t]{4}{*}{ Reputation } & Poor/excellent public image & \multirow{4}{*}{$\begin{array}{l}\text { Modified } \\
\text { from(McCole, } \\
\text { Ramsey, \& } \\
\text { Williams, 2010) }\end{array}$} \\
\hline & & Not/extremely committed to customer satisfaction & \\
\hline & & Products and/or services are extremely poor/excellent & \\
\hline & & Has an extremely poor/excellent reputation. & \\
\hline \multirow[t]{4}{*}{7} & $\begin{array}{l}\text { Re-purchase } \\
\text { intention }\end{array}$ & I will buy from this vendor again & \multirow{4}{*}{$\begin{array}{lr}\text { Adapted } & \text { from } \\
\text { (Zboja } & \& \\
\text { Voorhees, } & \\
2006) . & \end{array}$} \\
\hline & & I will do business with this manufacturer in the near future & \\
\hline & & I will keep on buying this product from this vendor & \\
\hline & & I will recommend this vendor to my friends too & \\
\hline
\end{tabular}

Table 3: Intra-class Correlation Coefficients of the Variables

\begin{tabular}{ll}
\hline Variable & ICC value \\
\hline Consumer Re-Purchase Intention & 0.032 \\
Vendor Reputation & 0.146 \\
Perceived Vendor trust & 0.042 \\
Customer expertise in using Website & 0.071 \\
Vendor expertise in order Fulfilment & 0.058 \\
Website Usability & 0.053 \\
Relationship quality & 0.032 \\
\hline
\end{tabular}


Hadi et al. / International Journal of Research in Business and Social Science,

Vol 8 No 4, 2019 ISSN: 2147-4486

Table 4: Overall reliability of the constructs and factor CFA loadings of indicators

\begin{tabular}{|c|c|c|c|c|c|c|c|}
\hline \multicolumn{2}{|c|}{ Construct Validity } & AVE & MSV & ASV & Cronbach $\alpha$ & Factor Loading & t-Value \\
\hline \multirow[t]{4}{*}{ PEO } & PEO1 & 0.560 & 0.450 & 0.175 & .884 & .736 & $17.524^{* * *}$ \\
\hline & PEO2 & & & & & .772 & $18.682^{* * *}$ \\
\hline & PEO3 & & & & & .658 & $15.024^{* * *}$ \\
\hline & PEO4 & & & & & .773 & $18.683^{* * *}$ \\
\hline \multirow[t]{5}{*}{ CSAT } & CSAT2 & 0.511 & 0.260 & 0.115 & 0.922 & .804 & $19.638^{* * *}$ \\
\hline & CSAT3 & & & & & .744 & $18.029^{* * *}$ \\
\hline & CSAT4 & & & & & .718 & $17.164^{* * *}$ \\
\hline & CSAT5 & & & & & .744 & $18.030^{* * *}$ \\
\hline & CSAT6 & & & & & .719 & $17.165^{\star \star *}$ \\
\hline \multirow[t]{4}{*}{ PR } & PR1 & 0.583 & 0.373 & 0.146 & 0.875 & .754 & $18.386^{* * *}$ \\
\hline & PR2 & & & & & .702 & $16.628^{* * *}$ \\
\hline & PR3 & & & & & .803 & $19.633^{* * *}$ \\
\hline & PR4 & & & & & .755 & $18.386^{* * *}$ \\
\hline \multirow[t]{7}{*}{ PWU } & PWU1 & 0.500 & 0.177 & 0.102 & 0.956 & .767 & $18.428^{* * *}$ \\
\hline & PWU2 & & & & & .715 & $17.044^{* * *}$ \\
\hline & PWU3 & & & & & .816 & $20.580^{* * *}$ \\
\hline & PWU4 & & & & & .803 & $19.633^{* * *}$ \\
\hline & PWU5 & & & & & .772 & $18.938^{* * *}$ \\
\hline & PWU6 & & & & & .772 & $18.682^{* * *}$ \\
\hline & PWU7 & & & & & .773 & $18.683^{* * *}$ \\
\hline \multirow[t]{5}{*}{ CUEX } & CUEX1 & 0.601 & 0.451 & 0.316 & 0.901 & .767 & $18.428^{* * *}$ \\
\hline & CUEX2 & & & & & .784 & $18.465^{\star * *}$ \\
\hline & CUEX3 & & & & & .782 & $18.465^{\star * *}$ \\
\hline & CUEX4 & & & & & .767 & $18.428^{* * *}$ \\
\hline & CUEX5 & & & & & .723 & $17.168^{* \star *}$ \\
\hline \multirow[t]{3}{*}{ VTRU } & VTRU1 & & & & & .724 & $17.168^{* * *}$ \\
\hline & VTRU2 & & & & & .684 & $15.468^{* * *}$ \\
\hline & VTRU3 & & & & & 0.654 & $15.761^{* *}$ \\
\hline
\end{tabular}

Note:

AVE represents average variance extracted. MSV represents maximum shared variance. ASV = represents average shared variance. CR represents construct or composite reliability. VTRU represents Vendor trust. CSAT represents customer satisfaction, ORI online re-purchase intention, PR represents vendor reputation, $P W U$ represents perceived website usability, CUEX represents customer experience in using online platform ${ }^{* * *}$ Significant at the 0.001 significance level. 